\title{
Properties of Different Mortars and their Effect on the Flexural Strength of Low Density Block Walls
}

\author{
Ash Ahmed and John Kamau
}

\begin{abstract}
Mortar is a very important adhesive material as it is used to fasten materials or components together to make a larger unit. It's most common application is to adhere masonry blocks or bricks thus allowing the construction of a single unit. The type of mortar used is important as it directly influences the mechanical behaviour of the masonry unit. This paper investigates the properties of different conventional (designations (iii) and (iv) as per BS 5628) and thin layer mortars and their influence on the flexural strength of low density aircrete wallettes, tested in accordance to BS EN 1052 (four point loading). The strengths of the wallettes were impressive and compare favourably to the values reported in BS 5628, especially the thin layer ones which exhibited excellent strength within 7 days curing time.
\end{abstract}

Index Terms-Autoclaved Aerated Concrete; Aircrete; Flexural Strength; Low Density Blockwork; Mortar; Thin Layer Mortar.

\section{INTRODUCTION}

Mortar is a very important material in civil engineering as it bonds together bricks and blocks in dwellings. Traditionally there are two different types of mortars: lime and cement. Lime mortar is the oldest type and has been used for centuries. This was the preferred type of mortar until cement mortars were developed. The disadvantage with lime mortars is that it gains maximum strength after 90 days, this can delay construction time which can confer negative economic implications.

The main advantage with cement based mortars is that it reaches maximum strength in only 28 days. There are four different types (designations) of cement mortars as shown in Table I.

With decreasing strength, there is increased flexibility, i.e. designation (iv) has the greatest flexibility. Typically designations (iii) and (iv) are used with low density blockwork, however, over the last 15 years or so, thin layer mortars have become increasingly popular as they provide greater flexural strength for the wall [2].

Thin layer mortar, as the name implies, is a special type of adhesive mortar with a mortar thickness of only $3 \mathrm{~mm}$ (in comparison to $10 \mathrm{~mm}$ for conventional mortars, including lime).

Although the layer is very thin, the mortar forms a very strong bond with the blocks. Furthermore, as the greatest heat loss through a wall is through the mortar layer,

Published on May 18, 2017.

A. Ahmed is with the Civil Engineering Group. Leeds Becket University, Leeds, UK (email: A.R.Ahmed@leedsbeckett.ac.uk)

J. Kamau is with the Civil Engineering Group. Leeds Beckett University, Leeds, England, UK (email: John.kamau@yahoo.com) reducing the mortar bed thickness can improve the thermal insulation of the dwelling [3].

This paper reports the findings of a study undertaken to verify the mechanical properties of different conventional cement and thin layer mortars as this can to an extent explain why only $3 \mathrm{~mm}$ joint thickness is required for thin layer mortars.

TABLE I: DiFFERENT DESIGNATIONS OF CEMENT BASED MORTARS AND Respective Mean Compressive Strength At 28 Days, as Per [1].

\begin{tabular}{ccccc}
\hline & Cement:Lime & Sand & & $\begin{array}{c}\text { Compressive } \\
\text { strength }\end{array}$ \\
\hline $\begin{array}{c}\text { Mortar } \\
\text { Designation }\end{array}$ & Ratio & Ratio & Known as & $\left(\mathbf{N} / \mathbf{m m}^{2}\right)$ \\
\hline (i) & $1: 01 / 4$ & 3 & $01: 03$ & 16 \\
\hline (ii) & $01: 00$ & 4 & $1: 1 / 2: 4$ & 6.5 \\
\hline (iii) & $01: 01$ & 6 & $01: 01: 06$ & 3.6 \\
\hline (iv) & $01: 02$ & $08-S e p$ & $01: 02: 09$ & 1.5 \\
\hline \hline
\end{tabular}

Aircrete (AAC) was initially developed in Scandinavia in the 1950s and it's first application was as a replacment for timber [4], [5]-[7]. Currently, AAC is a very popular building material, especially in Europe and North America. It is made from cement, fly ash (PFA), lime, sand and aluminium oxide powder. Given that PFA is an industrial by-product of the coal industry, AAC has very low embodied $\mathrm{CO}_{2}$, thus imparting substantial sustainability advantages.

The final structure of the material is very porous (up to $85 \%$ ), however, given the pores are evenly distributed, AAC imparts satisfactory mechanical and structural performance for the construction of two storey dwellings [5], [8]-[11].

Due to the high porosity content, AAC has very low thermal conductivity, thus provides very good thermal insulation [8], [12], [13]-[22] as shown in Table II.

In the UK AAC blocks typically have compressive strengths greater than $3 \mathrm{~N} / \mathrm{mm}^{2}(\mathrm{MPa})$, however, elsewhere in Europe lower strength AAC blocks are well established [4]-[7], [12], [16], [19]; therefore, utilising lower strength AAC blocks in the UK will facilitate in reducing greenhouse gas emissions as the buildings will be better insulated thus requiring less heating.

This paper reports the findings of a study undertaken to verify the properties of different types of mortars and their effect on the characteristic flexural strength of low density aircrete wallettes with both conventional and thin layer mortar. 
TABLE II: PHYSICAL PROPERTIES OF AIRCRETE BLOCKS

\begin{tabular}{cccc}
\hline \hline \multirow{2}{*}{$\begin{array}{c}\text { Aircrete } \\
\text { density }\end{array}$} & $\begin{array}{c}\text { Compressive } \\
\text { strength }\end{array}$ & Density & $\begin{array}{c}\text { Thermal } \\
\text { conductivity }\end{array}$ \\
\cline { 2 - 4 } & $\left(\mathbf{N} / \mathbf{m m}^{2}\right)$ & $\left(\mathbf{K g} / \mathbf{m}^{3}\right)$ & $(\mathbf{W} / \mathbf{m K})$ \\
\hline Low & $2.0-3.5$ & 450 & $0.09-0.11$ \\
\hline Medium & $4.0-4.5$ & 620 & $0.15-0.17$ \\
\hline High & $7.0-8.5$ & 750 & $0.19-0.20$ \\
\hline \hline
\end{tabular}

\section{EXPERIMENTAL}

Experimental work was undertaken to establish the mechanical properties of three mortars types (designations iii, iv and thin layer). A series of tests were carried out to evaluate the cube compressive, tensile and flexural strengths of conventional mortar prepared using $32.5 \mathrm{~N}$ and $42.5 \mathrm{~N}$ Portland cement and two types of thin layer mortar designated type $\mathbf{A}$ and $\mathbf{B}$.

The two cements were selected as there is no guidance on cement choice in the British code although there is some data on mortar strengths in Table 1 of [1], the relevant parts of which are reproduced as Table I of this paper. Flow properties of these mortars were also established.

Sample preparation and testing were carried out in accordance with appropriate Standards as documented in this paper.

This section is divided into two main parts. The first part gives details of test materials and mortar properties and the flexural testing follows this.

\section{MORTAR PROPERTIES: MATERIALS}

The first set of tests on cement were carried out using $42.5 \mathrm{~N}$ PC. Bulk lime was used in the mortar production. Soft building sand used complies with the requirements of BS 1200 [24] was used.

\section{SPECIMEN PREPARATION}

\section{A. Conventional Mortar}

Conventional mortar samples of designation (iii) and (iv) were produced to establish fresh and mechanical properties. Water was added so that the workability was consistent and corresponded to a $10 \mathrm{~mm}$ penetration of the dropping ball test as suggested in [1].

The flow properties were determined in accordance with [25]. The flow values obtained for all mixes fell within a range of between $186188 \mathrm{~mm}$.

\section{B. Thin Layer Mortar}

Again, mortar samples were produced to establish fresh and mechanical properties. Manufacturer's mixing guidelines, given in Table III were strictly followed - the mixture was stirred for approximately 10 minutes until a lump free paste was obtained and the workability was consistent and corresponded to a $9.5 \mathrm{~mm}$ penetration of the dropping ball test.

The flow values obtained for all mixes fell within a range of between 154 and $156 \mathrm{~mm}$. Both thin layer mortars were manufactured in accordance with [26].
TABLE III: MORTAR MIXING PREPARATION.

\begin{tabular}{ccc}
\hline \hline & Mortar A & Mortar B \\
\hline $\begin{array}{c}\text { Mortar Weight } \\
\text { (kg) }\end{array}$ & 25 & 25 \\
\hline $\begin{array}{c}\text { Water Content } \\
\text { (litres) }\end{array}$ & 4.4 & $5 / 5.5$ \\
\hline \hline
\end{tabular}

\section{Properties examined}

A range of properties were examined during experimental work as shown in Table IV. In all testing, three specimens were broken at each test age (Table IV). Tests were carried out in accordance with [27].

TABLE IV: MORTAR PROPERTIES AND TESTING REGIMES

\begin{tabular}{ccc}
\hline $\begin{array}{c}\text { Mortar } \\
\text { Property }\end{array}$ & Specimen & Test Age \\
\hline $\begin{array}{c}\text { Compressive } \\
\text { cube strength }\end{array}$ & $100 \times 100 \times 100 \mathrm{~mm}$ & $1-28$ days \\
\hline $\begin{array}{c}\text { Tensile } \\
\text { strength }\end{array}$ & Dog bone & 28 days \\
\hline $\begin{array}{c}\text { Flexural } \\
\text { strength }\end{array}$ & $40 \times 40 \times 160 \mathrm{~mm}$ & 28 days \\
\hline \hline
\end{tabular}

Test specimens were demoulded after 24hours of casting and then transferred into an Environmental Chamber where a constant temperature of $20{ }^{\circ} \mathrm{C}$ and relative humidity of $95 \%$ was maintained throughout.

\section{FleXURAL TESTING OF WALLETTES}

The flexural strength of the 2 and $2.8 \mathrm{~N}$ block wallettes were determined. The wallettes were built using designations (iii) and (iv) mortar (in accordnace to [1]) and two different types of thin layer mortars provided by $\mathrm{H}+\mathrm{H}$ Celcon and Clan.

The wallettes were prepared and tested in accordance to [21]. The dimensions of the blocks were the industrial standard: $440 \times 215 \times 150 \mathrm{~mm}$ for $2.8 \mathrm{~N}$ blocks and $620 \times$ $215 \times 150 \mathrm{~mm}$ for $2 \mathrm{~N}$ blocks. The wallette sizes were 1100 x $860 \mathrm{~mm}$ for $2.8 \mathrm{~N}$ blocks and 930 x $645 \mathrm{~mm}$ for $2 \mathrm{~N}$ blocks; unless specified otherwise the wallette thickness is $150 \mathrm{~mm}$.

The specimens were tested to destruction under a four point load and the resultant flexural strengths were determined as specified in [21]. The matrix of tested specimens is shown in Table $\mathrm{V}$.

TABLE V: MATRIX OF SPECIMENS TESTED

\begin{tabular}{ccccc}
$\begin{array}{c}\text { Aircrete } \\
\text { block } \\
\text { strength } \\
\left(\mathrm{N} / \mathrm{mm}^{2}\right)\end{array}$ & Mortar designation & Thin layer mo1 & $\begin{array}{c}\text { Thin } \\
\text { layer } \\
\text { mortar }\end{array}$ \\
\cline { 2 - 5 } & iii & iv & A & B \\
\hline 2.0 & $5 \mathrm{~B}$ & $5 \mathrm{~B}$ & $5 \mathrm{~B}$ & $15 \mathrm{~B}^{*}$ \\
\hline 2.0 & $5 \mathrm{P}$ & $5 \mathrm{P}$ & $5 \mathrm{P}$ & \\
\hline 2.8 & $\mathrm{x}$ & $\mathrm{x}$ & $5 \mathrm{~B}$ & $15 \mathrm{~B}^{*}$ \\
\hline 2.8 & $\mathrm{x}$ & $\mathrm{x}$ & $5 \mathrm{P}$ & \\
\hline \hline
\end{tabular}

In Table $\mathrm{V}, \mathrm{B}$ indicates the flexural strength is determined parallel to the bed (mortar) joints whereas $\mathrm{P}$ denotes the strength determined in the perpendicular plane to the bed joints.

As specified in [28] a minimum of 5 wallettes must be 
tested for each type of block / mortar combination; all designations (iii) and (iv) mortar wallettes were tested after 28 days curing. $* 15$ thin layer wallettes were constructed for testing after 1,7 , and 28 days curing due to the accelerated setting time for thin layer mortar.

\section{RESULTS}

\section{A. Compressive Strength Development of Mortar}

Table VI summarises the 28-day cube compressive, flexural and tensile strength test results of both designations iii and iv mortars. The compressive strength results of thin layer mortars cured up to 28-days are given in Table VII and plotted on Fig. 3 while Table VIII summarises 28-day compressive cube, flexural and tensile strength test results of these mortars.

TABLE VI: 28-DAY STRENGTH RESULTS OF DESIGNATIONS III AND IV

\begin{tabular}{ccccc}
\hline \hline $\begin{array}{c}\text { Cement } \\
\text { Type }\end{array}$ & $\begin{array}{c}\text { Mortar } \\
\text { Designation }\end{array}$ & $\begin{array}{c}\text { Compressive } \\
\text { Strength } \\
\left(\mathbf{N} / \mathbf{m m}^{2}\right)\end{array}$ & $\begin{array}{c}\text { Flexural } \\
\text { Strength } \\
\left(\mathbf{N} / \mathbf{m m}^{2}\right)\end{array}$ & $\begin{array}{c}\text { Tensile } \\
\text { Strength } \\
\left(\mathbf{N} / \mathbf{m m}^{2}\right)\end{array}$ \\
\hline $\begin{array}{c}42.5 \mathrm{~N} \\
\text { PC }\end{array}$ & iii & $7.7(3.6)$ & 4.9 & 4.8 \\
\cline { 2 - 5 } 32.5 N & iv & $4.1(1.5)$ & 2.4 & 1.8 \\
\cline { 2 - 5 } PC & iii & $4.3(3.6)$ & 2.3 & 1.7 \\
\hline \hline
\end{tabular}

TABLE VII: COMPRESSIVE STRENGTH RESULTS OF THIN LAYER MORTAR) ${ }^{1}$

\begin{tabular}{ccc}
\hline \hline \multirow{2}{*}{$\begin{array}{c}\text { Curing Age } \\
(\text { Days })\end{array}$} & \multicolumn{2}{c}{ Compressive Cube Strength $\left(\mathbf{N} / \mathbf{m m}^{2}\right)$} \\
\cline { 2 - 3 } & A (n*) & B (n) \\
\hline 1 & $7.5(2.1)$ & $2.9(0.8)$ \\
\hline 3 & $11.9(3.3)$ & $5.8(1.6)$ \\
\hline 7 & $14.9(4.1)$ & $8.6(2.4)$ \\
\hline 10 & $16.0(4.4)$ & $10(2.8)$ \\
\hline 14 & $17.0(4.7)$ & $11.5(3.2)$ \\
\hline 21 & $17.4(4.8)$ & $11.8(3.3)$ \\
\hline 28 & $17.6(4.9)$ & $12(3.3)$ \\
\hline \hline
\end{tabular}

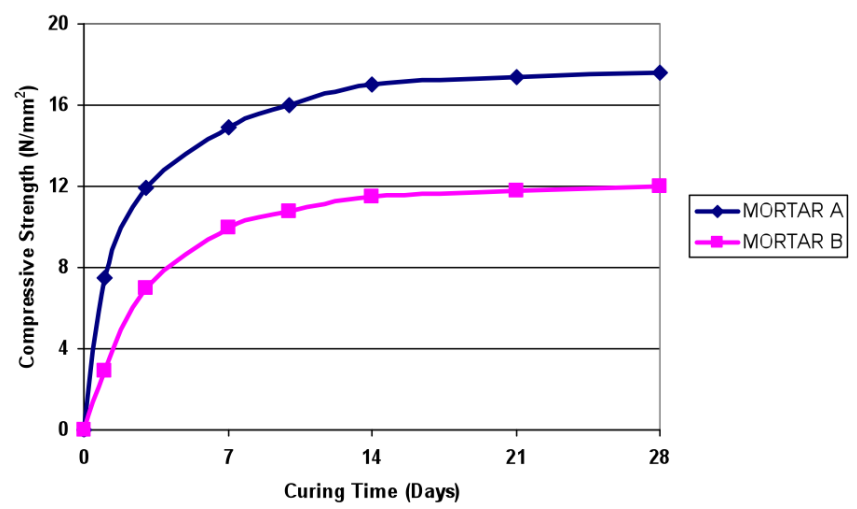

Fig. 1. Compressive Strength Development for Thin Layer Mortars.

TABLE VIII: 28-DAY STRENGTH RESULTS OF THIN LAYER MORTARS

\begin{tabular}{cccc}
\hline \hline Thin Joint & $\begin{array}{c}\text { Compressive } \\
\text { Mortar }\end{array}$ & $\begin{array}{c}\text { Flexural } \\
\text { Strength } \\
\left(\mathbf{N} / \mathbf{m m}^{2}\right)\end{array}$ & $\begin{array}{c}\text { Tensile } \\
\text { Strength } \\
\left(\mathbf{N} / \mathbf{m m}^{2}\right)\end{array}$ \\
A & 17.6 & 4.6 & 1.9 \\
B & 12.0 & 3.6 & 1.7 \\
\hline \hline
\end{tabular}

${ }^{1} \mathrm{NB}$ : bracketed numbers indicate how many times the thin joint mortars are stronger than the [1] specification for a designation (iii) mortar.

\section{B. Flexural strength of Aircrete Wallettes}

Table IX provides statistical analysis of results obtained for both Thin Layer mortars. Table X provides statistical analysis of results obtained for conventional mortars.

TABLE IX: STATISTICAL ANALYSIS OF FLEXURAL STRENGTH OF THIN LAYER WALLETTES

\begin{tabular}{ccccccc}
\hline \hline $\begin{array}{c}\text { Aircrete } \\
\text { block } \\
\text { strength } \\
\left(\mathrm{N} / \mathrm{mm}^{2}\right)\end{array}$ & $\begin{array}{c}\text { Curing } \\
\text { time } \\
\text { (days) }\end{array}$ & $\begin{array}{c}\text { Thin } \\
\text { layer } \\
\text { mortar }\end{array}$ & Direction & $\begin{array}{c}\text { Average } \\
\text { failure } \sigma \\
\left(\mathrm{N} / \mathrm{mm}^{2}\right)\end{array}$ & Standard & $\begin{array}{l}\text { Characteristi } \\
\text { c strength }\end{array}$ \\
\hline 2 & 28 & A & B & 0.3 & 0.017 & 0.27 \\
\hline 2 & 28 & B & B & 0.31 & 0.023 & 0.27 \\
\hline 2 & 28 & A & P & 0.28 & 0.013 & 0.26 \\
\hline 2 & 1 & B & B & 0.24 & 0.015 & 0.22 \\
\hline 2 & 7 & B & B & 0.3 & 0.01 & 0.28 \\
\hline 2.8 & 28 & A & B & 0.48 & 0.032 & 0.42 \\
\hline 2.8 & 28 & B & B & 0.48 & 0.023 & 0.44 \\
\hline 2.8 & 28 & A & P & 0.39 & 0.021 & 0.35 \\
\hline 2.8 & 1 & B & B & 0.22 & 0.017 & 0.19 \\
\hline 2.8 & 7 & B & B & 0.46 & 0.022 & 0.42 \\
\hline \hline
\end{tabular}

TABLE X: STATISTICAL ANALYSIS OF FLEXURAL STRENGTH OF WALLETTES MADE WITH CONVENTIONAL MORTAR

\begin{tabular}{cccccc}
\hline \hline $\begin{array}{c}\text { Aircrete } \\
\text { block } \\
\text { stresngth } \\
\left(\mathrm{N} / \mathrm{mm}^{2}\right)\end{array}$ & $\begin{array}{c}\text { Mortar } \\
\text { designtion }\end{array}$ & Direction & $\begin{array}{c}\text { Average } \\
\text { failure } \sigma \\
\left(\mathrm{N} / \mathrm{mm}^{2}\right)\end{array}$ & $\begin{array}{c}\text { Standard } \\
\text { deviation }\end{array}$ & $\begin{array}{c}\text { Characteristic } \\
\text { strength } \\
\left(\mathrm{N} / \mathrm{mm}^{2}\right)\end{array}$ \\
\hline 2 & iii & B & 0.17 & 0.013 & 0.15 \\
\hline 2 & iii & P & 0.22 & 0.014 & 0.2 \\
\hline 2 & iv & B & 0.17 & 0.018 & 0.14 \\
\hline 2 & iv & P & 0.21 & 0.023 & 0.17 \\
\hline \hline
\end{tabular}

\section{DISCUSSION}

\section{A. Mortar Properties}

With 42.5 N PC, the compressive strengths for designations (iii) and (iv) mortars are at least double than that specified in [1]. With the $32.5 \mathrm{~N}$ PC cement mortar, the 28 day strength is slightly higher than that specified in the code. Variations are probably due to different mortar consistencies and possibly type of sand used.

Thin Layer Mortar A has compressive strength nearly $50 \%$ greater than Mortar B but both mortars exceed the strength requirement of designation (iii) mortar as specified in [1] by significant amounts. The bracketed numbers in Table VII indicate how many times stronger these mortars are the 28 day strength of designation (iii) mortar. Mortar A at 1 day, is twice the 28day [1] specified strength, whilst mortar B at the same stage is 0.85 the [1] 28day strength and at 3 days is 1.6 times the 28 day strength. Both mortars give remarkably consistent flexural strength results using wallettes despite their discrepancy in strength [2].

For the conventional mortars reported in this paper, the strength development is approximately $45 \%$ after 7 days, however, for the thin layer mortars, nearly $75 \%$ of the final strength is reached after 7 days curing.

\section{B. Flexural Strength of Thin Layer Wallettes}

Table VIII shows excellent repeatability (low standard deviation) for flexural strengths. As per [1], the flexural strength for $7 \mathrm{~N}$ AAC blocks with designation (iv) mortar is 0.2 and $0.45 \mathrm{~N} / \mathrm{mm}^{2}$ for $\mathrm{B}$ and $\mathrm{P}$ wallettes respectively. 
The findings of this investigation show that the average strength of the thin layer mortar with 2 and $2.8 \mathrm{~N}$ blocks is substantially higher at 0.30 and $0.48 \mathrm{~N} / \mathrm{mm}^{2}$ respectively. The results also show very good consistency for 2 and $2.8 \mathrm{~N}$ blocks using either type of thin layer mortar.

In masonry the normal trend for walls is higher strength in the $\mathrm{P}$ direction in comparison to the $\mathrm{B}$ direction as the weakest part of any wall is typically along the mortar bed. However, the results here contradict this theory as the thin layer wallettes exhibit higher flexural strength in the $\mathrm{B}$ direction.

Comparing figs. 2 and 4 shows that thin layer wallettes typically incurred a large amount of material failure (fig. 2), however, all 2 and $2.8 \mathrm{~N}$ wallettes (fig. 4) using conventional mortar (designations (iii) and (iv)) failed entirely along the mortar bed (figs. 3 and 4). The findings suggest the thin mortar forms an exceptionally strong bond with the masonry blocks, therefore, a much larger stress is required to impart failure. Furthermore, as the bond strength along the perpendicular joints is expected to be inferior in relation to the mortar bed, this possibly explains why aircrete specimens with thin layer mortar are stronger in the B direction.

The results also show the rapid development of strength of wallettes with thin layer mortar, with maximum strength being attained after 7 days curing and for $2 \mathrm{~N}$ block wallettes nearly $80 \%$ of the maximum strength being reached after only 1 day curing. One thing to note is that after 1 day curing all aircrete wallettes using thin layer mortar fail in the $\mathrm{B}$ direction (fig. 3) as the bond between block and mortar hasn't fully developed. However, all thin layer mortar specimens exhibit predominant material failure after 7 days curing as shown in fig. 2, thus suggesting the full bond strength between block and mortar is reached within the 7 day period.

\section{Flexural Strength of Conventional Mortar Wallettes}

As per [1] the flexural strength of 2.8 to $7 \mathrm{~N}$ aircrete walletes (250 $\mathrm{mm}$ thick) with designations (iii) and (iv) mortar is reported as 0.15 and $0.1 \mathrm{~N} / \mathrm{mm}^{2}$; in the $\mathrm{P}$ direction the strengths are quoted as 0.25 and $0.2 \mathrm{~N} / \mathrm{mm}^{2}$ for designations (iii) and (iv) mortars respectively. In this research, the strengths of $2 \mathrm{~N}$ specimens are 0.15 and 0.20 $\mathrm{N} / \mathrm{mm}^{2}$ in the $\mathrm{B}$ and $\mathrm{P}$ directions respectively; this is in keeping with the aforementioned [1] values. Furthermore, the mode of failure for all aircrete wallettes using conventional designations (iii) and (iv) mortars were consistently along the mortar bed (fig. 4).

As expected the strengths of designation (iii) mortar wallettes are greater than designation (iv), although the strengths in the B directions are very similar.

The results of the wallettes are consistent and proportional to the strengths of the mortar (Tables VI and VII). The higher strength of the thin layer mortars results in a much greater bond strength between block and mortar.

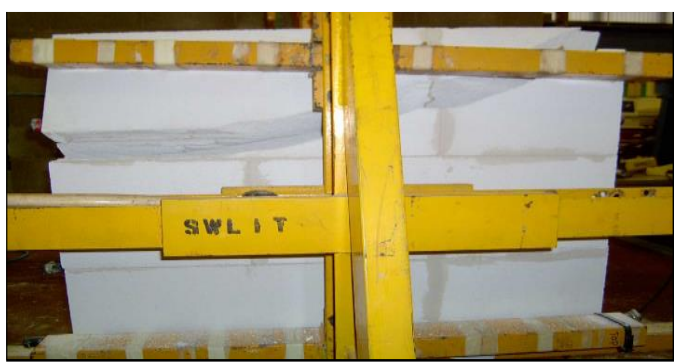

Fig. 2. Typical failure of a low density $(2 \mathrm{~N} / \mathrm{mm} 2)$ aircrete thin layer (mortar) wallette (after 7 and 28 days curing) in the B direction showing predominantly material failure.

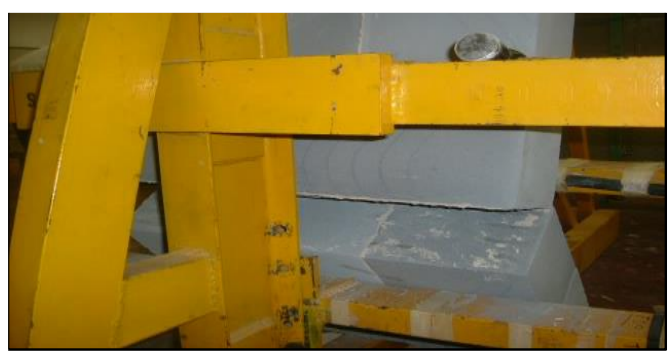

Fig. 3. Typical failure of a $2.8 \mathrm{~N} / \mathrm{mm} 2$ aircrete thin layer wallette (after 1 day curing) in the $\mathrm{B}$ direction showing failure occurring along the bed (mortar) joint.

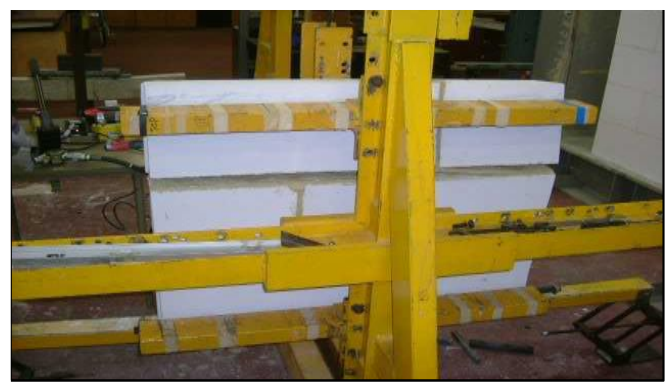

Fig. 4. Typical failure of a $2 \mathrm{~N} / \mathrm{mm} 2$ aircrete designation iii wallette (after 28 days) in the $\mathrm{B}$ direction showing failure occurring along the bed joint.

\section{CONCLUSIONS}

Key strength properties of different mortar types (designations iii, iv produced using $32.5 \mathrm{~N}$ and $42.5 \mathrm{~N}$ PC) and thin joint have been established. The characteristic flexural strength of low density aircrete wallettes made of 2.8 and $2 \mathrm{~N} / \mathrm{mm}^{2}$ blocks using these mortars was determined.

- $\quad$ Strengths of mortars produced using $32.5 \mathrm{~N}$ PC are considerably lower than those obtained for $42.5 \mathrm{~N}$ PC mortars.

- Mortar strengths from both 32.5PC and 42.5PC mortars exceed the values given in [1]

- The thin layer mortar type $\mathbf{A}$ was stronger than thin layer mortar type $\mathbf{B}$ at all ages.

- With both thin layer mortars $70 \%$ of the total strength was reached after 7 days curing.

- With both thin layer mortars, the strength at 3 days was at least 1.6 times greater (3.3 for mortar A) than the 28 day strength for designation (iii) mortar as required in Table 1 of [1].

- The strengths of B wallettes with thin layer mortar particular are relatively high in comparison to reported values, with very good repeatability (low standard deviation).

- The optimum flexural strength for thin layer 
wallettes are reached within 7 days curing time.

- The strengths of wallettes with conventional mortar were weaker than thin layer wallettes. However, the flexural strengths of both types of wallette compare favourably to values reported in the British Standard.

- The mode of failure for thin layer specimens in the B direction exhibited substantial material failure as opposed to de-bonding along the mortar bed.

\section{ACKNOWLEDGEMENT}

The authors would like to thank EPSRC and industrial collaborators (AACPA) for their funding and support.

\section{REFERENCES}

[1] BS 5628-1:1992 - Code of practice for use of masonry - Part 1: Structural Use of Un-reinforced Masonry.

[2] Ahmed, A., Flexural strength of low density blockwork, International Conference on Construction Materials and Structures, ICCMATS 2014, Johannesburg, South Africa.

[3] Ahmed, A., Fried, A., Roberts, J.J., Advantages and Implications of High Performance Low Density Aircrete Products for the UK Construction Industry, 13th International Brick and Block Masonry Conference (IBBMaC), Amsterdam, Netherlands 2004.

[4] H+H Celcon Ltd, www.hhcelcon.co.uk [accessed 24.1.17].

[5] The UK Aircrete Association, 2013, Code of Best Practice for the Use of AAC, www.aircrete.co.uk.

[6] Ahmed, A., Fried, A., Roberts, J.J., Advantages and Implications of High Performance Low Density Aircrete Products for the UK Construction Industry, 13th International Brick and Block Masonry Conference (IBBMaC), Amsterdam, Netherlands 2004.

[7] Bright, N., Ahmed, A., Concentrated Loads on Aircrete Thin Joint Blockwork, 14th International Brick and Block Masonry Conference (IBBMaC), Sydney, Australia 2008.

[8] Dubral, W., 1992, YTONG AG, Munich, Germany, Advances in Autoclaved Aerated Concrete, Wittmann (ed.) (C) Balkema, Rotterdam. ISBN 9054100869.

[9] Mitsuda, T., and Kiribayashi, T., 1992, Hydrothermal properties of autoclaved aerated concrete, Advances in Autoclaved Aerated Concrete, Wittmann (ed.) (c) Balkema, Rotterdam. ISBN 905410086 9.

[10] Callister, W., Jr., 2011, Department of Metallurgical Engineering, The University of Utah, Materials Science and Engineering - An Introduction, Seventh Edition, John Wiley and Sons, Inc, ISBN 9780471736967.

[11] Ungkoon et al, A study of hygrothermal performance of AAC blocks under humid climate of Thailand. International Conference "Passive and Low Energy Cooling for the Built Environment", Santorini, Greece 2005

[12] Thermalite, Hanson HeidelBerg Cement Group, www.heidelbergcement.com [accessed 18.3.17].

[13] Design for Homes, Application of Aircrete Blocks, www.designforhomes.org [accessed 8.2.17].

[14] Lippe, K., 1992, YTONG AG, R + D Centre, Schrobenhausen, Germany, The effect of moisture on the thermal conductivity of AAC, Advances in Autoclaved Aerated Concrete, Wittmann (ed.) C Balkema, Rotterdam. ISBN 9054100869.

[15] Liu, C., and Wang, J., 1992, An experimental study on thermal transmission properties of AAC panels, Advances in Autoclaved Aerated Concrete, Wittmann (ed.) (C) Balkema, Rotterdam. ISBN 90 54100869 .

[16] Tarmac Building products, AAC Blocks, www.tarmacbuildingproducts.co.uk [accessed 16.1.15].
[17] Quan, Y., Nianxiang, Y., Applications of AAC block in new energysaving building structure, Electric Technology and Civil Engineering (ICETCE) Conference, 1066-1069, Lushan, China 2011.

[18] Yuplng, Z., Dedong, L., Guokuang, S., Investigation into the Carbonation of Autoclaved Aerated Concrete, 8th International Congress on the Chemistry of Cement, 1996;5:93-98

[19] Wittman, F.H., 1993a, Autoclaved Aerated Concrete: Properties, Testing and Design, RILEM Recommended Practice, RILEM Technical Committees 78 - MCA and 51 - ALC.

[20] Tada, S., 1992, Texte, Inc. and Nihon University, Japan. Advances in AAC, Wittmann (ed.) () Balkema, Rotterdam. ISBN 9054100869.

[21] Jacobs, F., and Mayer, G., 1992, Institute for Building Materials, ETH Zurich, Switzerland, Advances in Autoclaved Aerated Concrete, Wittmann (ed.) (C) Balkema, Rotterdam. ISBN 9054100869.

[22] Schober, G., Hebel AG, Emmering, 1992, Germany, Effect of size distribution of air pores in AAC on compressive strength, Advances in AAC, Wittmann (ed.) (C) Balkema, Rotterdam. ISBN 905410086

[23] BS EN 197; Part 1- Cement Composition, Specifications and Conformity Criteria for Common Cements.

[24] BS 1200:1976 - Specifications for Building Sands from Natural Resources.

[25] BS EN 1015-3:1999 - Methods of Test for Mortar for Masonry - Part 3: Determination of consistence of fresh mortar (by flow table).

[26] BS EN 998-2:2003 - Specification for mortar for masonry. Masonry mortar.

[27] BS EN 1015-11:1999 - Methods of Test for Mortar for Masonry. Determination of Flexural and Compressive Strength of Hardened Mortar.

[28] British Standards b, BS EN 1052: Part 2: 1999 - Determination of Flexural Strength. Now incorporated into the Eurocode 6.

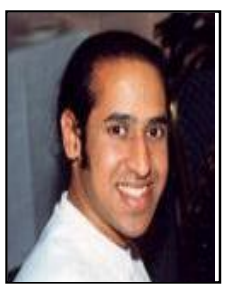

Ash Ahmed, the main author was born in Manchester, UK. He graduated with a Bachelor of Science with honors degree in Materials Science from Manchester University, United Kingdom (UK) and a Master of Philosophy degree in Metallurgy from the University of Manchester, UK. He then completed his $\mathrm{PhD}$ in Polymer Science from Heriot-Watt University, Edinburgh, UK.

$\mathrm{He}$ has been a Senior Lecturer at Leeds Beckett University since 2005, teaching modules in materials science at undergraduate and postgraduate levels. Previously Head of Civi Engineering, Dr Ahmed has several publications in the field of sustainable masonry and concrete materials. His area of research is in the field of sustainable construction materials using recycled and waste products

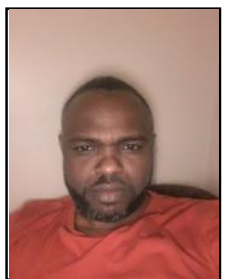

J. Kamau was born in Kenya. He graduated with a Bachelor of Science with honours degree in civil engineering from Leeds Beckett University, Leeds, West Yorkshire, United Kingdom (UK) in 2010 and a Master of Science degree in structural engineering from the University of Leeds, Leeds, West Yorkshire, UK in 2011. He is currently undertaking a research programme on supplementary cementitious materials at the Leeds Beckett University, Leeds, West Yorkshire, UK.

He has worked in the past as a CIVIL ENGINEER and is currently working as a STRUCTURAL ENGINEER in Barnsley, South Yorkshire, UK. John already has several publications in the field of novel supplementay cement materials in concrete.

Mr. Kamau is a Graduate Member of the Institution of Civil Engineers (GMICE) 